Tropical Journal of Pharmaceutical Research February 2017; 16 (2): 255-261

ISSN: $1596-5996$ (print); 1596-9827 (electronic)

(C) Pharmacotherapy Group, Faculty of Pharmacy, University of Benin, Benin City, 300001 Nigeria.

All rights reserved.

Available online at http://www.tjpr.org

Original Research Article

http://dx.doi.org/10.4314/tjpr.v16i2.1

\title{
Antibodies against Shigella flexneri adhesion molecule outer membrane protein (OMP) can cross-react with OMPs of some Shigella species
}

\author{
Alvi Milliana ${ }^{1}$, AS Noorhamdani ${ }^{2}$, Sri Poeranto ${ }^{3}$, Kusworini Handono ${ }^{4}$, Sumarno \\ Reto Prawiro ${ }^{2 \star}$, Avin Ainur Fitrianingsih ${ }^{1}$ and Lailia Nur Rachma ${ }^{1}$ \\ ${ }^{1}$ Biomedic Magister Programme, ${ }^{2}$ Laboratory of Microbiology, ${ }^{3}$ Laboratory of Parasitology, ${ }^{4}$ Laboratory of Clinical Chemistry, \\ Medical Faculty of University Brawijaya, Malang, Indonesia
}

${ }^{*}$ For correspondence: Email: retoprawiros@yahoo.com; Tel: 081555840099

Received: 15 September 2016

Revised accepted: 20 January 2017

\begin{abstract}
Purpose: To identify a Shigella flexneri hemagglutinin outer membrane protein (OMP) as an adhesion factor and examine its ability to cross-react with the OMPs of other Shigella species.

Methods: OMP was isolated from the bacterium S. flexneri after shaving the pili using a pili bacterial cutter in a solution of $0.5 \%$-octyl- $\beta$-D-glucopyranoside. Hemagglutination was evaluated using mice erythrocytes. The molecular weight (MW) of the OMPs was profiled by SDS-PAGE. Adhesion molecules were identified by calculating the index of adhesion. Thereafter, antigen cross-reaction with antibodies was examined by Western blotting,

Results: The S. flexneri adhesion molecule OMP has a MW of $28 \mathrm{kDa}$. An antibody against the $28 \mathrm{kDa}$ S. flexneri OMP adhesion molecule cross-reacted with different MW OMPs from other Shigella species. Conclusion: This study showed that the $28 \mathrm{kDa}$ S. flexneri OMP is a hemagglutinin adhesion protein, and antibodies against it can cross-react with the OMPs of other Shigella species.
\end{abstract}

Keywords: Shigella flexneri OMP, Outer membrane protein, Protein adhesion, Antibody, Cross-reaction

Tropical Journal of Pharmaceutical Research is indexed by Science Citation Index (SciSearch), Scopus, International Pharmaceutical Abstract, Chemical Abstracts, Embase, Index Copernicus, EBSCO, African Index Medicus, JournalSeek, Journal Citation Reports/Science Edition, Directory of Open Access Journals (DOAJ), African Journal Online, Bioline International, Open-J-Gate and Pharmacy Abstracts

\section{INTRODUCTION}

Diarrhea is the fourth leading cause of morbidity and mortality worldwide, and Shigella species cause an estimated 164.7 million cases of diarrhea annually. In developing countries, the 163.2 million cases resulted in 1.2 million deaths [1]. In South Jakarta, the predominant isolate was $S$. flexneri, which is often isolated in other developing regions, such as Bangladesh, Pakistan, and
Africa [2]. S. flexneri is endemic in developing countries $[1,3]$.

Shigella is a highly infectious pathogen, because only $10-100$ ingested bacteria are sufficient to cause disease [4]. The success of a pathogenic bacterial infection requires attachment to host cells, tissue colonization, and cell invasion [5].

The initial stage of infection is adhesion between the bacteria and host cells. 
Outer membrane proteins (OMPs) include proteins that mediate the attachment of bacteria to the host cell more closely than do pili [6,7]. A 49.8 $\mathrm{kDa}$ Shigella dysenteriae hemagglutinin pili protein that serves as an adhesion protein was found previously [8]. Oral immunization with this $49.8 \mathrm{kDa} S$. dysenteriae protein can increase intestinal secretory $\lg A(s-\lg A)$ levels, inhibit bacterial colonization in the colon, and prevent damage to colon epithelial cells [9]. There are two $S$. dysenteriae pili protein subunits, of 7.9 and $49.8 \mathrm{kDa}$. The $S$. dysenteriae protein prevented diarrhea in a mouse ligated ileal loop (MLIL) model [10].

The World Health Organization (WHO) has prioritized the development of safe, effective vaccines for shigellosis, and several candidate vaccines are being developed currently $[1,11]$. OMPs have been used successfully as vaccine antigens to prevent Lyme disease and pertussis based on their roles as adhesion molecules [11-13]. The ideal Shigella vaccine should be able to induce an immune response against all Shigella spp. [11].

\section{EXPERIMENTAL}

\section{Sample preparation}

The bacteria Shigella flexneri 4a, Shigella dysenteriae 2a, Shigella boydii serotype 10, and Shigella sonnei were obtained from the Yogyakarta Regional Health Laboratory. Culture isolates of the Shigella species were grown on MacConkey medium at $37^{\circ} \mathrm{C}$ for $24 \mathrm{~h}$ and then transferred to Petri dishes containing Salmonella-Shigella Agar (SSA) medium at $37{ }^{\circ} \mathrm{C}$ for $24 \mathrm{~h}$. The resulting bacterial cultures were dissolved in $10 \mathrm{~mL}$ phosphate-buffered saline (PBS) ( $\mathrm{pH} 7.4$ ), added to bottles containing $500 \mathrm{~mL}$ Brain Heart Infusion
$(\mathrm{BHI})$, and shaken in a water bath for 30 $\min$ at $37^{\circ} \mathrm{C}$.

\section{Isolation of OMP}

The Shigella OMP was isolated in two stages. The first stage involved cutting the bacterial cell pili, and the second involved isolating the OMP from the bacterial cell after pili cutting, as described in our previous study [14]. The OMP was isolated according to the method of Evans and Evans [15]. The pellet from the last centrifugation step was resuspended in PBS $(\mathrm{pH}$ 7.4) until the volume reached 15 -fold, and then $n$ octyl- $\beta$-D-glucopyranoside was added at concentrations up to $0.5 \%$. The resulting solution was homogenized using a vortex and centrifuged at $12,000 \mathrm{rpm}$ at $4{ }^{\circ} \mathrm{C}$ for $15 \mathrm{~min}$. This treatment was repeated three times to give a supernatant rich in OMP.

\section{Purification of Shigella spp. OMP}

The molecular weight of the OMP was determined using sodium dodecyl sulfate-polyacrylamide gel electrophoresis (SDS-PAGE) [16]. The OMP was purified by electroelution [12]. The elution product was dialyzed for 24 $\mathrm{h}$ in a glass beaker with sterile PBS and stirred at $4{ }^{\circ} \mathrm{C}$ for $24 \mathrm{~h}$. The obtained protein was precipitated by centrifugation at $12,000 \mathrm{rpm}$ for $15 \mathrm{~min}$ at $4{ }^{\circ} \mathrm{C}$.

\section{Hemagglutination test}

The hemagglutination test was performed according to the method of Hanne and Finkelstein with modifications [14]. First, $50 \mu \mathrm{L}$ PBS were placed in the wells of a Microplate V, and $50 \mu \mathrm{L}$ serial dilutions of the sample were added. Then, $50 \mu \mathrm{L} 0.5 \%$ mice erythrocyte suspension were added to each well, and the plate was shaken gently for 1 min on a plate rotator. The hemagglutination titer was the lowest 
dilution causing agglutination of the red blood cells.

\section{Isolation of mouse enterocytes}

Mice enterocytes were isolated using the Weisser method [17]. The mice were anesthetized using chloroform, their stomachs opened, and the small intestines removed. The small intestine was cut into small pieces and washed several times until clean using a solution of PBS containing $1 \mathrm{mM}$ dithiothreitol (DTT) at $4{ }^{\circ} \mathrm{C}$. Then, the intestinal tissue was added to a solution containing 1.5 $\mathrm{mM} \mathrm{KCl}, 9.6 \mathrm{mM} \mathrm{NaCl}, 27 \mathrm{mM} \mathrm{Na}$ -

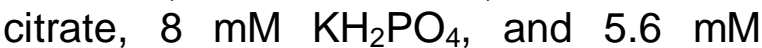
$\mathrm{Na}_{2} \mathrm{HPO}_{4}$ at $\mathrm{pH}$ 7.4. The solution was incubated on a shaking incubator at 37 ${ }^{\circ} \mathrm{C}$ for $15 \mathrm{~min}$. The supernatant was discarded and the tissue was transferred to a solution containing $1.5 \mathrm{mM}$ EDTA and $0.5 \mathrm{mM}$ DTT. The liquid was shaken vigorously for $15 \mathrm{~min}$ at $37^{\circ} \mathrm{C}$, and the supernatant was discarded. The tissue was washed with PBS and then centrifuged at $1500 \mathrm{rpm}$ at $4{ }^{\circ} \mathrm{C}$ for 5 $\mathrm{min}$; this was repeated at least three times until the supernatant was clear. Enterocytes were obtained after centrifugation at $1500 \mathrm{rpm}$ for $5 \mathrm{~min}$ and resuspended in PBS. For the adhesion test, $10^{6}$ enterocytes $/ \mathrm{mL}$ were used.

\section{Adhesion test}

The adhesion test was performed according to the method of Nagayama et al. with modifications [14]. S. flexneri was cultured in $\mathrm{BHI}$ liquid for $24 \mathrm{~h}$ at 37 ${ }^{\circ} \mathrm{C}$ and then centrifuged at $6000 \mathrm{rpm}$ at 4 ${ }^{\circ} \mathrm{C}$ for $10 \mathrm{~min}$. The pellet was resuspended in PBS containing $1 \%$ bovine serum albumin. The bacterial count was set at $10^{8} / \mathrm{mL}$ using a spectrophotometer at a wavelength of $600 \mathrm{~nm}$. Then, $0,6.25,12.5,25,50$, or $100 \mu \mathrm{g}$ of OMP was added to $300 \mu \mathrm{g}$ of the enterocyte suspension and rocked gently on a shaking water bath at $37^{\circ} \mathrm{C}$ for $30 \mathrm{~min}$.

Finally, $300 \mu \mathrm{g}$ of the bacterial suspension $\left(10^{8} / \mathrm{mL}\right)$ were added to each mixture, incubated on a shaking incubator for $30 \mathrm{~min}$ at $37^{\circ} \mathrm{C}$, and then centrifuged at $1500 \mathrm{rpm}$ at $4{ }^{\circ} \mathrm{C}$ for 3 min. The pellet was washed twice with PBS. A sample was smeared on a glass slide and subjected to Gram staining.

\section{Immunization of mice with $S$. flexneri OMP}

The study used 6-8-week-old male $B A L B / C$ mice. The antigen used was the purified $28 \mathrm{kDa} S$. flexneri hemagglutinin adhesion OMP. Mice were acclimatized for 7 days before immunization. After acclimatization, the mice were injected intraperitoneally with $100 \mu \mathrm{g}$ OMP that had been emulsified with $0.1 \mathrm{~mL}$ complete Freund's adjuvant [18].

\section{Isolation of polyclonal antibodies}

Blood was collected from the hearts of the mice, placed in an Eppendorf tube, which was left tilted for $30 \mathrm{~min}$, and then centrifuged at $10,000 \mathrm{rpm}$ for $5 \mathrm{~min}$. The supernatant serum was stored at $-20^{\circ} \mathrm{C}$ [8].

\section{Antigen/antibody cross-reactions}

The cross-reaction of Shigella spp. OMP antigen with antibody against the $S$. flexneri $28 \mathrm{kDa}$ OMP was examined by Western blotting. Before performing the antigen antibody response test, the checkerboard test was necessary to determine the effectiveness of the antigen and antibody reactions to be evaluated. The checkerboard test uses a dot blot method and reacts the $S$. flexneri $28 \mathrm{kDa}$ OMP antigen with serially diluted antibodies. The antigen was diluted $1 / 5$ to $1 / 10240$, and the antibody was diluted $1 / 100$ to $1 / 2800$. The results reveal a color gradation that can be analyzed using Corel Photo-Paint 
to determine the mean value [19]. Western blotting was performed using the method of Towbin et al [20].

\section{Statistical analysis}

The data were analyzed using SPSS 23. One-way analysis of variance with Tukey's post hoc test was used to determine significant differences in the mean index of adhesion among the sample groups. Pearson's correlation test was used to determine correlations between the sample doses and adhesion index. Significance level was set at $p<$ 0.05 .

\section{RESULTS}

\section{OMP Shigella spp profiling}

Figure 1 shows the molecular weights of the four Shigella species OMPs determined using SDS-PAGE. The profiles of the Shigella spp. OMPs were identical. There were various Shigella spp. OMPs, including OMPX, OMPA, OMPT, OMPLA, TOLC, a-hemolysin, porin OMP32, FhuA, and FEPA [5].

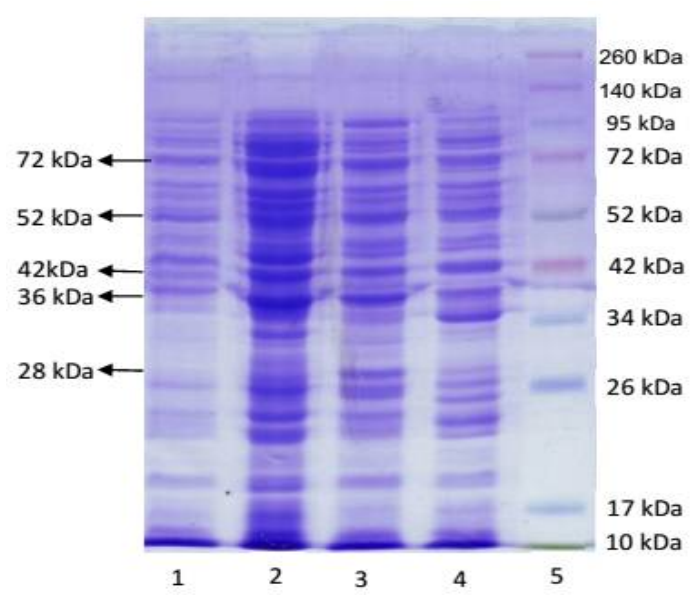

Figure 1: The results of $12.5 \%$ SDS-PAGE of Shigella OMPs. Note: Lane 1, S. boydii OMP; lane 2, S. dysenteriae OMP; lane 3, S. flexneri OMP; lane 4, S. sonnei OMP; lane 5, marker

\section{Hemagglutination}

The $S$. flexneri OMP bands with molecular weights of $28,36,42,52$, and $72 \mathrm{kDa}$ were identified as candidate adhesion proteins. These five protein bands were excised, collected, and purified by electro elution and dialysis for the hemagglutination test. The hemagglutination test results shown in Figure 2 indicated that the $28 \mathrm{kDa}$ OMP had the highest hemagglutination titer $(1 / 32)$, and thus it was selected for the adhesion tests.

\section{Adhesion}

The adhesion test was conducted using 0 (control), 6.25, 12.5, 25, 50, and 100 $\mu \mathrm{g}$ of the $28 \mathrm{kDa}$ S. flexneri OMP (Figure 3). The adhesion index was calculated by counting the number of bacteria attached to 100 enterocytes. The result is shown in Table 1, which shows that the number of $S$. flexneri attached to mouse enterocytes decreased with increasing OMP dose. There was a significant and strong negative correlation between the dose and adhesion index $(p=0.000)$. This proved that OMP inhibited the attachment of $S$. flexneri to enterocytes. 


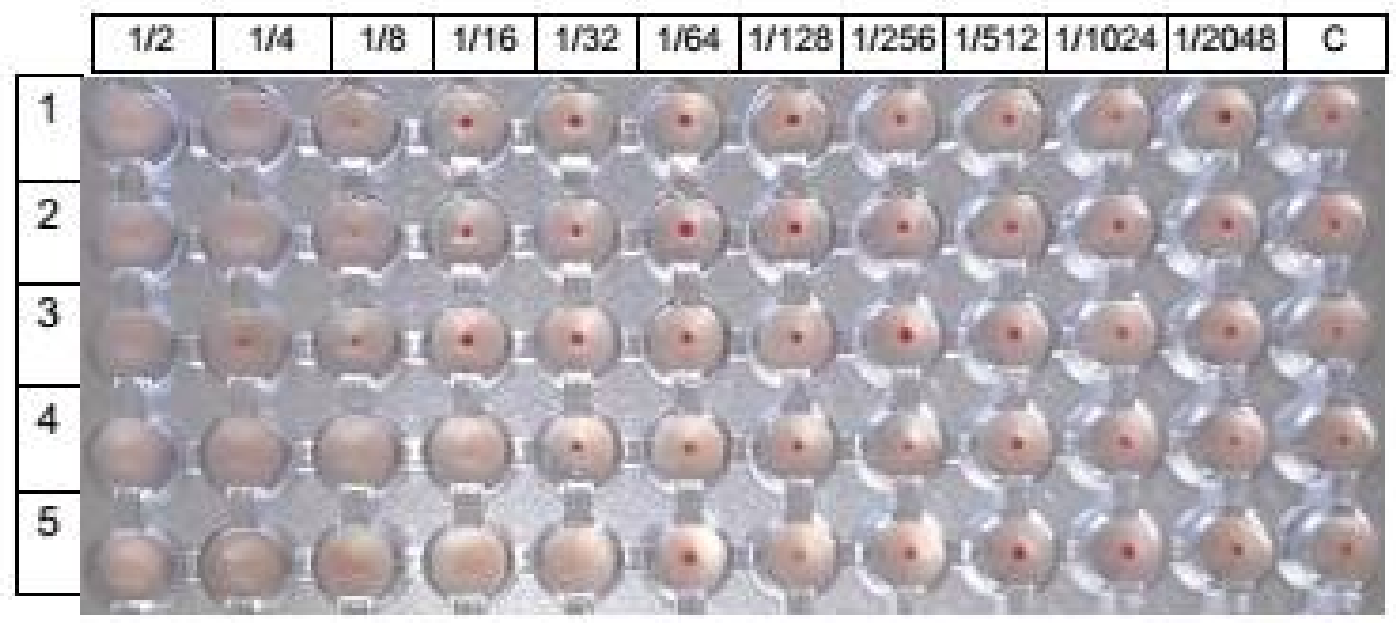

Figure 2: The results of the hemagglutination assay using mice erythrocytes and various molecular weight fractions of S. flexneri OMPs. Note: Lane C, negative control containing erythrocytes and PBS; no clumping of the erythrocytes was observed; lane 1, 72 kDa OMP; lane 2, 52 kDa OMP; lane 3, 42 kDa OMP; lane 4, 36 kDa OMP; lane 5, 28 kDa OMP
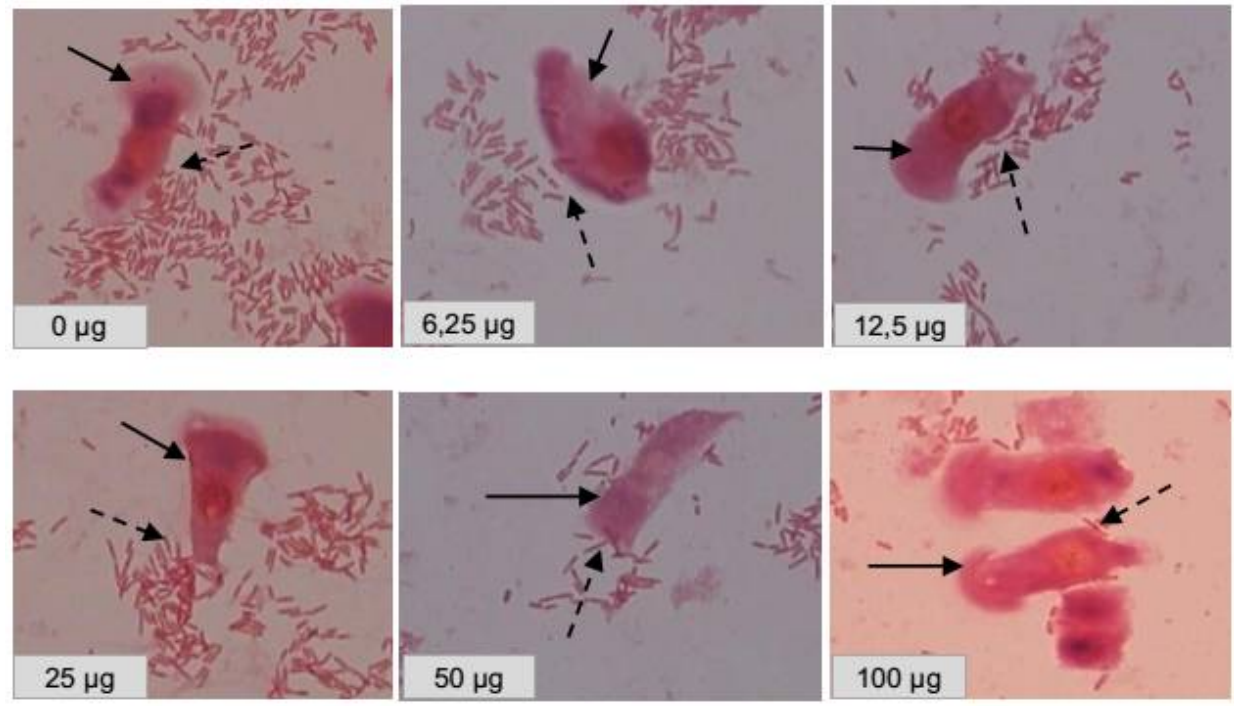

Figure 3: Adhesion test using the $28 \mathrm{kDa}$ S. flexneri OMP and mouse enterocytes

Black arrow ( t, enterocytes; dotted arrow ( ), S. flexpericells. Gram staining, 1000x magnification

Table 1: Correlation of various doses of OMP S. flexneri with adhesion index $(n=4)$

\begin{tabular}{lccc}
\hline Doses $(\boldsymbol{\mu g})$ & Mean \pm SD & $\boldsymbol{P}$-value & $\begin{array}{c}\text { Pearson } \\
\text { correlation }\end{array}$ \\
\hline 0 (control) & $1427.8 \pm 265.8$ & & \\
6.25 & $1244 \pm 69.4$ & & \\
12.5 & $785.5 \pm 148.1$ & $0.000<\alpha$ & -0.786 \\
25 & $596.0 \pm 20.2$ & & \\
50 & $437.8 \pm 28.2$ & & \\
100 & $332.3 \pm 31.8$ & & \\
\hline
\end{tabular}

\section{Antigen/antibody cross-reaction}

In the checkerboard test, the $S$. flexneri OMP antigen diluted $1 / 320$ and antibodies against the $28 \mathrm{kDa} S$. flexneri OMP diluted 1/400 showed the lowest density (data not shown). In this zone, there is a balanced antigen to antibody ratio. In Western blotting, antibodies against the $28 \mathrm{kDa} S$. flexneri OMP diluted 1/400 reacted with Shigella spp. OMP. 
In Figure 4, lane 1 represents the $28 \mathrm{kDa}$ $S$. flexneri OMP reacting with the antibody against the $28 \mathrm{kDa} S$. flexneri OMP, demonstrating that the $28 \mathrm{kDa} S$. flexneri OMP is an antigen capable of stimulating an antibody response. OMPs from other Shigella spp. (Figure 4, lanes 2 to 4) also reacted with the $28 \mathrm{kDa} S$. flexneri OMP antibody.

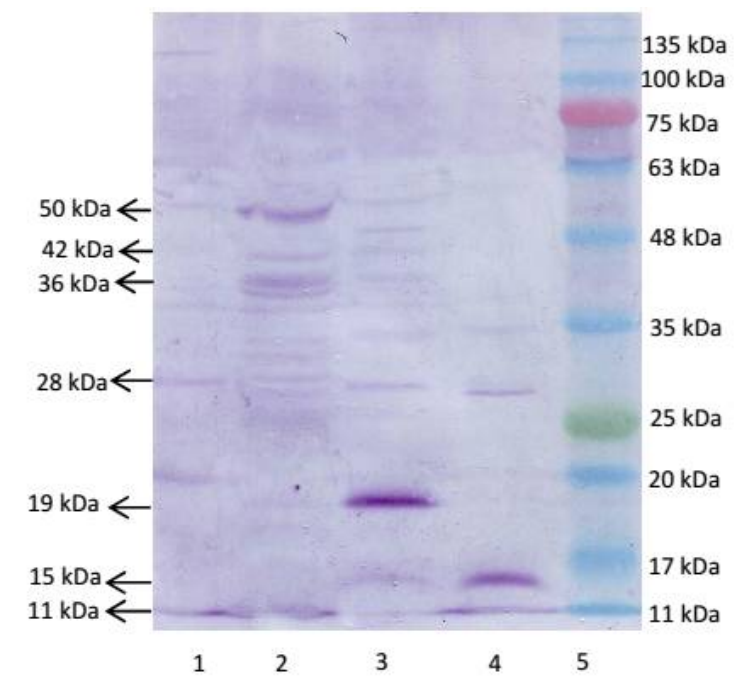

Figure 4: Western blotting of the Shigella spp. OMPs using an antibody against the $28 \mathrm{kDa} S$. flexneri OMP. Note: Lane 1, S. flexneri OMP; lane 2, S. dysenteriae OMP; lane 3, S. sonnei OMP; lane 4, S. boydii OMP; lane 5, marker

\section{DISCUSSION}

Shigellosis is caused by four Shigella species: $S$. flexneri, S. dysenteriae, S. boydii, and $S$. sonnei [4]. Shigella spp. OMP was isolated after shaving the bacteria pili using a pili bacterial cutter. The profiles of the Shigella spp. OMPs on SDSPAGE gels were identical, and their calculated molecular weights were similar. The number of OMP bands observed on SDS-PAGE gels indicated that Shigella species expressed many OMPs of various molecular weights, including OMPX, OMPA, OMPT, OMPLA, TOLC, $\alpha-$ hemolysin, porin OMP32, FhuA, and FEPA [5].

The S. flexneri $28 \mathrm{kDa} \mathrm{OMP}$ had the highest hemagglutination titer (1/32). Hemagglutination is an indicator of the ability of bacteria to attach to animal cells, because the erythrocyte membrane receptor is homologous to the mucosal host cell surface receptors [21].In order to confirm that the $S$. flexneri $28 \mathrm{kDa} \mathrm{OMP}$ is an adhesion protein, we conducted adhesion tests. The results showed that the adhesion of $S$. flexneri to mouse enterocytes was inhibited by the $S$. flexneri $28 \mathrm{kDa}$ OMP, as shown in Table 1 and Figure 3. There was a significant $(p=0.000)$ correlation between the dose and adhesion index. Therefore, OMP was able to inhibit the attachment of $S$. flexneri to enterocytes. We conclude that the $28 \mathrm{kDa} S$. flexneri OMP was an adhesin protein and a bacterial virulence factor [10]. Histopathological studies have demonstrated that inflammatory lesions in shigellosis are caused by the entry of bacteria into the upper rectum and distal colon. [4]. Immunization of mice with the $49.8 \mathrm{kDa}$ S. dysenteriae pili adhesion protein resulted in minimal colonic epithelial cell damage with elevated sIgA levels. s-lgA binds to intracellular enterocyte antigens, minimizing the destruction of epithelial cells in the intestinal mucosa [9]. The $49.8 \mathrm{kDa} S$. dysenteriae pili adhesion protein also protected against the movement of solution from the intestine to lumen in the MLIL model [14].

The antigen-antibody cross-reaction examined by Western blotting showed that many Shigella spp. OMPs reacted with the antibody against the $S$. flexneri $28 \mathrm{kDa}$ OMP (Figure 4). Therefore, the OMP antibody would be capable of recognizing epitopes present in the OMPs of all Shigella species. Antibodies produced against one antigen may bind to a different structurally related antigen, referred to as a cross-reaction [22].These results are consistent with another research who detected crossreaction between a $34 \mathrm{kDa}$ OMP and intact cells of Shigella species. An antibody against the $34 \mathrm{kDa}$ S. flexneri OMP recognized an epitope on the surface of $S$. flexneri [23]. After identifying the antigen-antibody response to Shigella OMPs, we 
postulated that the antibody would also prevent the adhesion of Shigella to the host cell, and hence could serve as a candidate shigellosis vaccine against all Shigella species.

The $34 \mathrm{kDa}$ S. flexneri OMP has already been purified with a promising subunit vaccine candidate for shigellosis [11, 23]. Our hemagglutinin assay also showed a positive result for a $36 \mathrm{kDa} S$. flexneri OMP, which may also be an adhesion molecule (Figure 2).Mitra et al found that the colonization ability of Shigella spp. was directly correlated with the hemagglutination activity in a suckling mouse model [24]. A recent in vivo study by Hamong et al. showed that a $49.6 \mathrm{kDa}$ Helicobacter pylori hemagglutinin protein prevented damage to the stomach caused by homologous bacteria in mice [25].

We postulated that adhesion molecule epitopes are involved in protein hemagglutinin due to various OMPs [14]. This finding should be clarified before developing peptide vaccines based on molecule adhesion epitopes.

\section{CONCLUSION}

A $28 \mathrm{kDa}$ S. flexneri OMP is identified here in this study as a hemagglutinin protein that serves as an adhesion protein. Antibodies against this protein cross-react with the OMPs of other Shigella species. Further research is needed to determine whether the $28 \mathrm{kDa}$ S. flexneri OMP hemagglutinin adhesion protein can protect against colon epithelial cell damage and the movement of solution into the intestinal lumen in MLIL model [10].

\section{DECLARATIONS}

\section{Acknowledgement}

This study was supported by Indonesian Ministry of Health in the scheme of IpTekDok 2014.

\section{Conflict of Interest}

No conflict of interest associated with this work.

\section{Contribution of Authors}

The authors declare that this work was done by the authors named in this article and all liabilities pertaining to claims relating to the content of this article will be borne by them.

\section{Open Access}

This is an Open Access article that uses a funding model which does not charge readers or their institutions for access and distributed under the terms of the Creative Commons Attribution License (http://creativecommons.org/licenses/by 14.0) and the Budapest Open Access Initiative (http://www.budapestopenaccessinitiative.org/rea d), which permit unrestricted use, distribution, and reproduction in any medium, provided the original work is properly credited.

\section{REFERENCES}

1. Kotloff $K L$, Winickoff JP, Ivanoff $B$, Clemens $J D$, Swerdlow DL, Sansonetti PJ, Adak GK, Levine MM. Global burden of Shigella infections: implications for vaccine development and implementation of control strategies. Bull World Health Organ 1999; 77(8): 651666.

2. Herwana E, Surjawidjaja JE, Salim OC, Indriani $N$, Bukitwetan $P$, Lesmana M. Shigella-associated diarrhea in children in South Jakarta, Indonesia. Southern Asian J Trop Med Public Health 2010; 41(2): 418-425.

3. WHO. Guidelines for the control of shigellosis, including epidemics due to Shigella dysenteriae type 1. WHO Document Production Services, Geneva, Switzerland. 2005.

4. Sansonetti PJ. Shigellosis: From symptoms to molecular pathogenesis. Am J Physiol Gastrointest Liver Physiol 2001; 280: G319-G323.

5. Schulz GE. The structure of bacterial outer membrane proteins. Biophys Acta 2002; 1565:308-317.

6. Nizet $V$, Esko JD. Bacterial and viral infections. Essentials of Glycobiology. 2nd Edition. NCBI-Book Shelf, La Jolla, California. 2009.

7. Wilson BW, Salyers AA, Whitt DD, Winkler ME. Bacterial strategies for evading or surviving host defense systems. In, Bacterial Pathogenesis: A Molecular Approach. 3rd Edition. ASM Press, Washington, 2011; pp 193-205.

8. Agustina $W$, Fitri LE, Raras TYM, Siswanto $B$, Sumarno $R P$. Antibody protein hemagglutinin subunit pili with MW 49.8 kDa Shigella dysenteriae can inhibit Shigella dysenteriae. IOSR J of Phar 2012; 2(5): 13-20. 
9. Setyorini D, Yulian DU, Widjayanto E, Winarsih $S$, Noorhamdani AS, Sumarno RP. Protectivity of adhesion molecules pili $49.8 \mathrm{kDa}$ Shigella dysenteriae conjugated with ISCOM against bacterial colonization and colonic epithelial cells damage. Int J Trop Med 2013; 8(1): 1926

10. Sumarno RP, Winarsih S, Hidayat S, Utami YW. Shigella dysenteriae pili proteins as an adhesive molecule can protect moving solution by using mice legated ilea loop model. Int J Trop Med 2015; 10(1-2): 1-4.

11. Pore $D$, Chakrabarti MK. Outer membrane protein $A$ (OmpA) from Shigella flexneri 2a: A promising subunit vaccine candidate. Vaccine 2013; 31: 3644-3650.

12. Livey I, O'Rourke M, Traweger A, Savidis-Dacho $H$, Crowe BA, Barrett PN, Yang X, Dunn JJ, Luft BJ. A new approach to a Lyme disease vaccine. Clin Infect Dis 2011; 52(Supp/ 3): 266-270.

13. WHO. Pertussis vaccines: position paper - September. Wkly Epidemiol Rec 2015; 90(35): 433-458.

14. Sumarno RP, Avanita AS, Winarsih $S$, Hidayat $S$, Nurhidayati DY. Haemaglutination of Shigella dysenteriae subunit pili protein with and antihaemaglutination of Shigella dysenteriae subunit pili protein as a molecule adhesion in mouse enterocytes. Afr J Med Res 2015; 9(11): 781-787.

15. Evans DG, Evans, DGYR. New surface-associated heatlabile colonization factor antigen (CFA/II) produced by enterotoxigenic Escherichia coli serogroups 06 and 08. Infect Immun 1978; 21: 638-647.

16. Laemmli UK. Cleavage of structural protein during the assembly of the head of bacteriophage T4. Nature 1970; 227: 680-668.
17. Weisser MM. Intestinal epithelial cell surface membrane glycoprotein synthesis. an indicator of cellular differentiation. J Biol Chem 1973; 248(7): 2536-2541.

18. Fuller SA, Takahashi M, Hurrell JGR. Current Protocol in Molecular Biology. John Wiley \& Sons, 2000. downloaded on February, 2, 2015.

19. Salah BMS, Kusworini H, Sumarno RP. Sensitivity and specificity of OMP Acinetobacter baumannii antigen dot blot to detect secretory-lgA in urine of patients with Acinetobacter baumannii infection. IOSR J Pharm Biol Sci 2014; 9(5): 06-15.

20. Towbin H, Stahelin T, Gordon J. Electrophoretic transfer of protein from polyacrylamide gels to nitrocellulose sheets. Proc Nat Acad Sci, 1979; 76: 4350-4354.

21. Nakazawa $T$, Ishibashi $M$, Konish $H$, Takemoto $T$, Shigeeda M, Kochiyama T. Haemaglutination activity of Campylobacter pylori. Infect Immun 1989; 57: 989-991.

22. Abbas, AK, Lichtman, AH, Pillai, S. Cellular and Molecular Immunology 7th Edition. USA: Elsevier Saunders. 2012; $p 104$

23. Pore D, Chowdhury P, Mahata N, Pal A, Yamasaki S, Mahalanabis D, Chakrabarti MK. Purification and characterization of an immunogenic outer membrane protein of Shigella flexneri 2a. Vaccine 2009; 27: 58555864.

24. Mitra S, Saha DR, Pal A, Niyogi SK, Mitra U, Koley $H$. Hemagglutinating activity is directly correlated with colonization ability of shigellae in suckling mouse model Can J Microbiol 2012; 58: 1159-1166.

25. Hamong S, Sumarno RP, Mantik IN, Hendrayana MA. In vivo confirmation of a $49.6 \mathrm{kDa}$ protein pili of Helicobacter pylori to prevent destruction of gastric cells against live homologous bacteria in mice. Int $J$ Phar Sci Res 2015; 6(3): 1049-1053. 